\title{
PENINGKATAN PERANAN WANITA DALAM PENGEMBANGAN USAHA RUMAH TANGGA
}

\author{
Wasis Gunadi \\ Dosen Tetap Prodi Manajemen Unsurya \\ wasisgunadi@yahoo.com
}

\begin{abstract}
ABSTRAK
Peranan wanita dalam dunia usaha dari waktu ke waktu mengalami peningkatan, baik jumlah maupun macam industri yang dipilih sebagai jenis usahanya, khususnya industri jasa. Dari sekitar 60 juta Usaha Mikro, Kecil dan Menengah (UMKM), 60\% diantaranya adalah UMKM wanita.

Perdagangan dan investasi bebas yang semakin mempertajam persaingan antar pelaku usaha pada hampir seluruh industri, menuntut agar produk UMKM memiliki daya saing yang lebih kuat. Dari tiga strategi bersaing: cost leaderships, product differentiation, dan focus, yang paling memungkan ditempuh dan dikembangkan oleh UMKM adalah strategi kedua, utamanya melalui pengembangan produk kreatif, khas dan up-dated. Pengembangan produk kratif ini harus merupakan upaya sinergis melibatkan pemerintah, Lembaga akademis, pelaku usaha dan masyarakat.

Produk-produk UMKM memiliki daya saing yang baik, khususnya di pasar luar negeri seperti saat berpameran Hongkong Fashion Week, Malaysian Halal Showcase (MIHAS), dan Dubai Global Village (DGV).
\end{abstract}

Key word : Peranan wanita, rumah tangga

\section{PENDAHULUAN}

Lebih dari $95 \%$ pelaku usaha di Indonesia terdiri dari pelaku Usaha Mikro, Kecil dan Menengah (UMKM), jumlahnya hampir mencapai 60 juta UKM, 60\% diantaranya merupakan UMKM wanita (Kementerian KUKM, 2016). UMKM ini berbaur dan bersaing dengan Usaha Menengah dan Besar (UMB), dan terbukti tangguh menghadapi krisis ekonomi yang sering membuat UMB kewalahan.
Perdagangan dan investasi bebas makin mempertajam persaingan antar pelaku usaha pada hampir seluruh industri, baik pada industri manufaktur, pertanian maupun jasa. UMKM Wanita memiliki beberapa keunggulan yang jarang dimiliki oleh UMKM pria antara lain proaktif, kreatif dan berani mengambil inisiatif dalam meningkatkan kesejahteraan khususnya kesejahteraan keluarganya, serta cenderung lebih bertanggung jawab dan professional dalam mengelola keuangan. Hal ini terlihat 
dari Non Performing Loan (NPL) pengusaha wanita hanya mencapai $3 \%$, bahkan tunggakannya sebesar nol persen. Beberapa karakteristik pengusaha wanita tersebut di atas membuat pengusaha wanita dinilai mampu menghadapi persaingan usaha pada era perdagangan dan investasi bebas yang berlangsung semakin intens.

Andalan UMKM menghadapi persaingan usaha pada era ini adalah melalui pengembangan produk yang inovatif, kreatif, khas dan ter-up date secara berkala. Sumberdaya yang tersedia di Indonesia sangat melimpah, baik SDM (sebagai sumber ide), sumberdaya alam (sebagai sumber bahan baku), maupun keberagaman suku dengan budayanya yang khas, sehingga sangat mendukung terwujudnya pengembangan produk tersebut di atas.

Pengembangan produk kreatif sangat melekat dengan karakteristik UMKM wanita yang menggemari kreativitas. Oleh karenanya berbagai event pameran produk kreatif di dalam dan luar negeri umumnya didominasi oleh UMKM wanita seperti Indonesia
International Expo, Jember Fashion Week, Hong Kong Fashion Week, Malaysian Halal Showcase (MIHAS), Dubai Global Village, dll.

Oleh karenanya peningkatan peranan wanita dalam dunia usaha menjadi suatu keharusan, yang seringkali dimulai dari usaha rumah tangga. Seperti Azka Fashion di Bogor, bermula dari usaha rumahan, yang memfokuskan pada produk busana muslim. Produk-produk Azka Fashion unik, selalu di up-date dan multifungsi karena sebuah produk Azka cocok dikenakan untuk kerja di kantor, pengajian, berbelanja, bahkan untuk "ngerumpi". Saat ini Azka Fashion sudah menjadi "inti" dari "plasma" yang terdiri dari ibu-ibu rumah tangga sekitarnya yang menjadi mitra usaha, karena omset yang semakin besar (mencapai puluhan milayar rupiah per bulan). Pasar utamanya adalah seluruh wilayah NKRI Malaysia dan Dubai.

Permasalahan utama yang
dihadapi UMKM antara lain
terbatasnya permodalan, kualifikasi
SDM yang umumnya menengah
kebawah dan rendahnya penguasaan


teknologi. Keterbatasan-keterbatasn tersebut di atas utamanya diatasi antara lain melalui peningkatan akses kepada pemanfaatan fasilitasi yang tersedia khususnya pada lembagalembaga pemerintah seperti Kementerian Koperasi, Usaha Kecil dan Menengah, Kementerian Perindustrian, dan Kementerian Perdagangan, perbankan dan Pemda setempat. Fasilitasi sejenis juga tersedia di berbagai lembaga swasta seperti Astra dengan program Pengembangan Mitra Usaha UMKM.

\section{TUJUAN}

1. Memberikan gambaran umum peranan wanita dalam pengembangan usaha UMKM.

2. Memotivasi kaum wanita untuk menggali potensi dirinya untuk berperan sebagai pelaku usaha wanita yang sukses pada industri yang dipilih sesuai dengan sumberdaya yang dimiliki, agar dapat meningkatkan daya saing produknya.

3. Mendorong dan membimbing UMKM wanita untuk mengembangkan usaha dengan strategi yang tepat sesuai dengan sumberdaya dan minat yang dimilikinya.

4. Memberikan informasi dan akses untuk mendayagunakan fasilitas yang disediakan oleh lembaga terkait dengan pengembangan daya saing produk UMKM.

5. Memotivasi UMKM wanita untuk belajar melihat peluang-peluang bisnis yang bisa dilakukan, dan membantu menetapkan langkahlangkah awal dan atau mengembangkan bisnis yang sudah dijalankan, utamanya melalui pemanfaatan fasilitasi lembagalembaga yang terkait dalam pengembangan produk yang berdaya saing.

\section{PENGEMBANGAN PRODUK} UMKM YANG BERDAYA SAING

Semakin ketatnya persaingan pada era perdangan dan investasi bebas direspon oleh pelaku-pelaku usaha dengan strategi bersaing yang bervariasi, yang menurut Porter (1980;35) terdiri dari Overall Cost Leaderships (kepemimpinan harga), Product Differentiation (menawarkan 
product yang "tampil beda"), dan Focus (hanya melayani ceruk pasar tertentu). Strategi pertama mengharuskan pelaku usaha beroperasi dalam skala besar agar bisa menjual produknya dengan harga paling murah. Strategi kedua memerlukan investasi besar juga jika berlomba menghasilkan/memasarkan produk yang berkualitas, namun bisa juga tidak harus bermodal besar jika andalannya adalah produk yang khas, inovatif dan kreatif agar bisa "tampil beda". Sedangkan strategi ketiga hanya bersifat lokal, karena hanya melayani ceruk pasar tertentu yang biasanya terkait dengan suku dan budaya.

Memperhatikan keterbatasanketerbatasan yang ada, maka bagi UMKM, strategi bersaing yang paling mungkin ditempuh adalah strategi Product Differentiation, yaitu menghasilkan dan mengembangkan produk yang inovatif, kreatif dan khas. Melimpahnya SDM, sumberdaya alam, serta beragam dan khasnya budaya, menjadi modal utama UMKM Indonesia untuk menghasilkan produk kreatif dan khas, sehingga memiliki daya saing khususnya pada pasar internasional. Untuk itu pembinaan dan pengembangan

UMKM menghasilkan produk kreatif dan khas menjadi prioritas, agar produk UMKM berdaya saing. Namun produk dimaksud harus selalu di up-date sesuai dengan permintaan pasar yang selalu berubah khususnya trend desainnya.

Pengembangan produk kreatif harus dilakukan secara terintegrasi melibatkan UMKM (sebagai pelaku usaha penghasil produk), pemerintah (fasilitator dan regulator), lembaga akademis (pendamping, pencetus dan pengembang ide), dan masyarakat (pengguna produk). Beberapa fasilitas yang disediakan oleh lembagalembaga terkait dalam pengembangan produk kreatif perlu dimanfaatkan secara optimal oleh UMKM. Lembaga-lembaga akademis khususnya terkait dengan pengembangan produk kreatif utamanya yang memiliki jurusan seni rupa (baik PTN maupun PTS). 


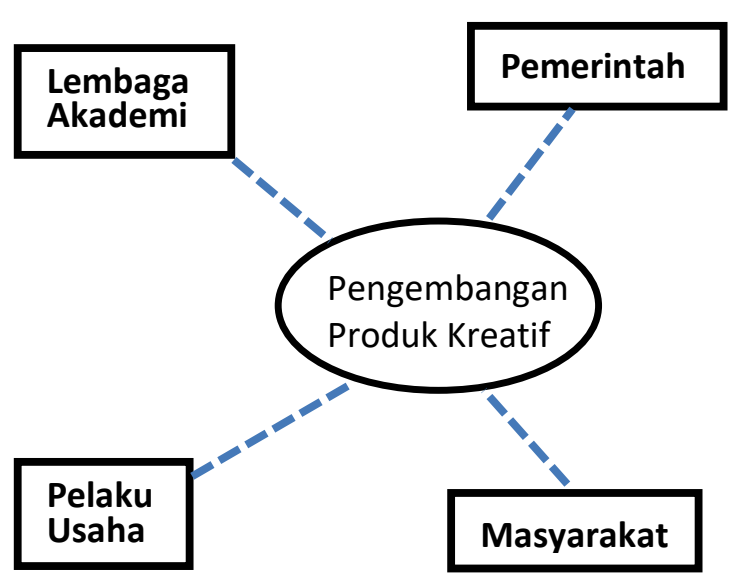

Pola Pengembangan Produk Kreatif UMKM Terintegrasi

Lembaga-lembaga pemerintah yang menyediakan fasilitasi terkait pengembangan produk kreatif antara lain Kementerian Perindustrian dan Kementerian Koperasi, Usaha Kecil dan Menengah, serta Pemda setempat. Beberapa program yang disediakan antara lain Program Pendampingan dalam Pengembangan Produk Kreatif UMKM, Penyediaan Buku Trend Desain khususnya terbitan Carlin International (yang di up-date setiap tahun), Program Pengembangan Kemasan, Pembiayaan dalam rangka Pengembangan Produk Kreatif, dan lain-lain. Adapun masyarakat sebagai pengguna produk UMKM harus dilibatkan peran aktifnya, khususnya dalam memberi umpan balik atas produk UMKM yang dikonsumsinya, yang harus direspon dan ditindaklanjuti oleh UMKM. Sejalan dengan upaya dan program-program tersebut, UMKM juga didorong untuk mempunyai sensitivitas terhadap trend desain yang selalu berubah, antara lain yang dapat diikuti perkembangannya melalui Google Searching.

Pengembangan produk kreatif sangat erat kaitannya dengan pengembangan trend desain produk. Terdapat banyak program pemerintah terkait dengan pengembangan trend desain produk tersebut. Dalam program tersebut pemerintah menyediakan pendamping (akademisi), Buku Trend Desain Internasional, pembiayaan khususnya untuk bahan baku, serta akses pada program terkait seperti pengembangan kemasan, patent, dll.

Dalam program pengembangan produk kreatif, UMKM peran pendamping (akademisi) terutama adalah membantu dan membimbing/melatih UMKM dalam menciptakan ide, membuat prototype produk dan produk akhir. UMKM berperan sebagai pemberi informasi 
produk baru yang ditemuainya di pasaran, sedangkan pemerintah berperan sebagai penyedia fasilitas yang dibutuhkan oleh UMKM dan pendamping terkait dengan pengembangan desain produk kreatif.

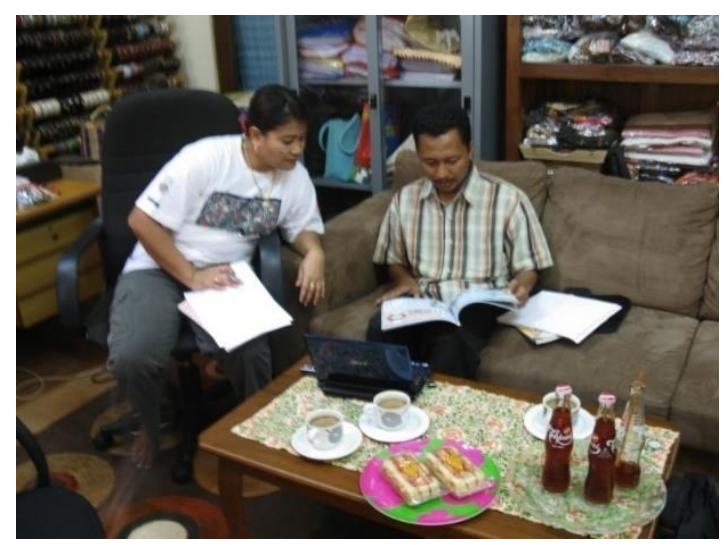

PENDAMPINGAN UMKM OLEH DESAINER MENGACU PADA BUKU TREND DESAIN CARLIN INTERNATIONAL
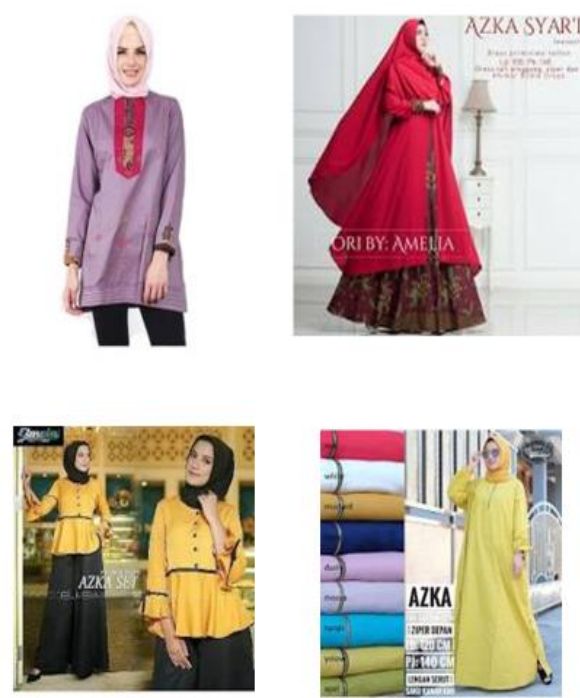

Beberapa contoh produk Azka Fashion
PENGEMBANGAN PASAR DAN

\section{PEMASARAN PRODUK UMKM}

Pengembangan pasar produk UMKM dilakukan setelah UMKM mampu menghasilkan produk yang berdaya saing. Sedangkan produk UMKM yang belum memiliki daya saing yang cukup, didorong untuk mengikuti program pengembangan produk kreatif tersebut di atas agar lebih berdaya saing. Sasaran pengembangan pasar dan pemasaran produk UMKM adalah pasar dalam dan luar negeri.

UMKM dapat memanfaatkan program-program pengembangan pasar dan pemasaran produkproduknya, baik yang disediakan oleh pemerintah maupun lembaga-lembaga lainnya. Lembaga-lembaga pemerintah yang menyediakan program-program tersebut antara lain Kementerian Perdagangan, Kementerian Koperasi dan UKM, Kementerian Perindustrian, dan Pemda setempat. Programprogramnya antara lain penyediaan space/kios, promosi, pengembangan kemasan, hak patent, pelatihan pemasaran, pameran-pameran baik di dalam negeri maupun di luar negeri. Pameran-pameran produk UMKM di 
dalam negeri yang dapat dimanfaatkan antara lain Jakarta International Expo, pameran/display produk-produk UMKM secara permanen antara lain yang disediakan oleh Kementerian Koperasi dan UKM, Kementerian Perindustrian, Pemda, dan Kementerian Perdagangan khususnya yang disediakan oleh kedutaanKedutaan Besar RI di luar negeri.

Khusus untuk pameran di luar negeri, UMKM dimotivasi/didorong agar memiliki produk yang berdaya saing, terutama produk yang kreatif, inovatif dan khas. Untuk itu program pengembangan produk yang berdaya saing sebaiknya diikuti oleh UMKM yang berorientasi ekspor. Beberapa UMKM (wanita) selain Azka Fashion yang sudah berhasil menembus dan mengembangkan pasar ekspor setelah mengikuti program-program tersebut di atas, antara lain "Bless Valentina" (Jakarta) dan CV "Batu cantik" (Denpasar). Awalnya, UMKMUMKM wanita ini memulainya dari "usaha rumahan".

\section{PENUTUP}

Pelaku usaha wanita, karena keunggulan-keunggulan yang secara alamiah dimilikinya, mempunyai peluang yang besar untuk menjadi pelaku usaha yang sukses. Untuk itu diperlukan motivasi, kreativitas, inovasi dan kemauan untuk terus menerus mengikuti perkembangan permintaan pasar, agar dapat menghasilkan dan memasarkan produk yang berdaya saing. Usaha yang semula berlingkup rumahan saja, sangat mungkin untuk dikembangkan menjadi usaha yang lebih luas ruang lingkupnya. Jadi, kalimat kuncinya adalah "kemauan kuat dan terus menerus untuk menggali dan mengembangkan produk-produk kreatif, khas dan selalu diperbarui (up-dated)".

\section{DAFTAR PUSTAKA}

Porter, Michael E. 1980. Competitive Strategy. The Free Press, a Division of Macmillan, Inc. 866 Third Avenue, New York, NY 10022.

Porter, Michael E. 1985. Competitive Advantage. The Free Press, a Division of Macmillan, Inc. 866 Third Avenue, New York, NY 10022.

Porter, Michael E. 1990. Competitive Advantage of Nations. The Free Press, a Division of 
Simon \& Schuster Inc. 1230 Avenue of the Americas, New York, NY 10020.

Laporan Tahunan Kementerian KUKM RI tahun 2016. 2017. Kementerian KUKM RI.

Kotler, Philip and Keller, Kevin Lane. $2012 . \quad$ Marketing Management. Pearson Education, Inc publishing as Prentice Hall, One Lake Street, Upper Saddle River, New Jersey 07458.

Carlin International. 2012. Design Prediction. Unpublished. 